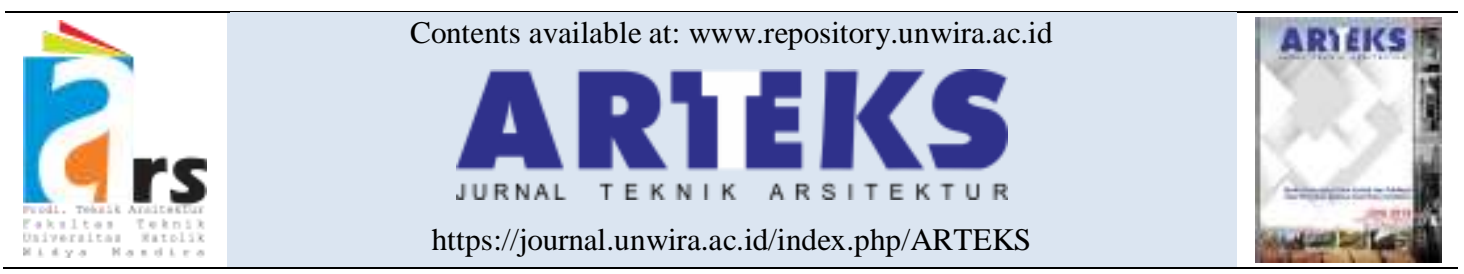

Research paper

doi: $10.30822 /$ arteks.v6i2.839

\title{
Identifying geometric configuration of earthquake-resistant buildings
}

\author{
Livian Teddy ${ }^{*}$, Johannes Adiyanto ${ }^{(\mathbb{D}}$, Husnul Hidayat \\ Department Architecture, Faculty of Engineering, Universitas Sriwijaya \\ Jl. Palembang-Prabumulih KM. 32, Indrajaya, Indonesia
}

\begin{tabular}{|c|c|}
\hline ARTICLE INFO & ABSTRACT \\
\hline $\begin{array}{l}\text { Article history: } \\
\text { Received December } 18,2020 \\
\text { Received in revised form Dec. } 31,2020 \\
\text { Accepted March } 14,2021 \\
\text { Available online August } 01,2021 \\
\end{array}$ & $\begin{array}{l}\text { Indonesia is an earthquake-prone area because it is located at the } \\
\text { world's most active tectonic plates and hundreds of local faults. } \\
\text { Obviously, there have been many earthquake victims caused by } \\
\text { collapsed buildings, hence the need for earthquake-resistant } \\
\text { construction. However, there is not much guidance for architects to }\end{array}$ \\
\hline $\begin{array}{l}\text { *Corresponding author: Livian Teddy } \\
\text { Department Architecture, Faculty of } \\
\text { Engineering, Univesitas Sriwijaya, Indonesia } \\
\text { Email: livianteddy@gmail.com } \\
\text { ORCID: https://orcid.org/0000-0002-0275- } \\
\text { 598X }\end{array}$ & $\begin{array}{l}\text { design earthquake-resistant buildings. This research proposes } \\
\text { guidance for architects on how to design building forms relatively } \\
\text { able to resist earthquakes. The simulation experiment method } \\
\text { involving } 32 \text { building models in various forms was employed. The } \\
\text { experimental results were then analyzed with modal analysis in } \\
\text { ETABS and SVA for architectural design. Based on the analysis } \\
\text { report, some guidelines were proposed: } 1) \text {. Avoid buildings that are } \\
\text { too slender, use the slenderness ratio } H / D \leqslant 2,2) \text {. Avoid soft stories } \\
\text { where the ratio of the top column height }(h) \text { to the bottom column } \\
\text { height (h1) } \leqslant 0.8,3) \text {. Use symmetrical shapes with } 1 \text { or } 2 \text { axes and } \\
\text { avoid shapes with random compositions, } 4) \text {. Use the additive and } \\
\text { subtractive mass transformation } \leqslant 15 \%, 5) \text {. Strengthen the } \\
\text { structural elements, install shear walls, or use dilatation to minimize } \\
\text { potential torsional irregularities and non-parallel system } \\
\text { irregularities of } L, T, U,+, \text { and } Z \text { forms6). Avoid using non-axial } \\
\text { asymmetrical forms. }\end{array}$ \\
\hline
\end{tabular}

\section{Introduction}

According to the 2016 earthquake catalog published by PUSGEN (Tim Pusat Studi Gempa Nasional 2017), from 1900 - 2016, there were 50.000 earthquakes with a magnitude of $\mathrm{Mw}>5$ in Indonesia. These earthquakes were caused by subduction earthquakes as a result of the movement of some tectonic plates like the IndoAustralian plate, the Eurasian plate, the Pacific plate, the Philippine Sea plate, and the movement of local faults such as the Great Sumatra fault (the Semangko fault), the Lembang fault and etc. From earthquakes occurring in 2004 - 2010 only, more than 250.000 people had died. Most of the victims died because the buildings fell on them, hence the need for earthquake-resistant buildings
(Kementerian Pekerjaan Umum dan Perumahan Rakyat 2010).

Designing earthquake-resistant buildings certainly needs effective collaboration between architects and structural engineers (Arnold and Stewart 2000; Hoedajanto and Riyansyah 2015). Many codes and guides are related to this type of buildings, but only a few are made for architects (Özmen and Ünay 2007). This study strives to give a small contribution to architects in the form of guidance in designing geometric configurations of earthquake-resistant buildings. This research involved 32 building models with basic and complex geometric forms as the configurations. Simulations were then conducted using ETABS dan SVA for architectural design to comprehend the deformation behavior of each model as a result of earthquake loads. After 
conducting simulations, the strengths and weaknesses of each model were compiled as the guidance for architects to design earthquakeresistant buildings.

\section{Method}

The quantitative method with the experimental simulation was used in this research. There were 32 models for simulation, and they were assumed as the representation of the basic geometric forms (models 0 to 3 ), the subtractive and additive transformation forms (models 04, 11, 13, 18, 21, $23 \mathrm{~B}, 25)$, the composition of the basic forms (models 05, 06. , 07, 08, 09, 10, 12, 19, 20, 22, 24, 26, 26B, 26C, 27, 27C, 27E), and organic/curved forms (models 14, 15). In addition, the strong earthquake zone ( $S S=1.5$ and $S 1=0.6)$, the soft ground site class, and the office buildings were also simulated in this research.

The structural system which was used is the moment resisting frame. The height of the building model was 10 floors except for models 13 to 15 , which were only 7 floors. The height between floors was $4 \mathrm{~m}$, except for the column of the first floor in model 16 and model 17 (6 m), The beam dimension was $0.25 \times 0.4 \mathrm{~m}$, except for model 11 (using beam combination $0.25 \times 0.4 \mathrm{~m}$ and $0.25 \times 1.0 \mathrm{~m}$ ), model 15 (using beam combination $0.3 \times 0.6 \mathrm{~m}$ and $0.25 \times 0.5 \mathrm{~m})$, model 26 (using beam combination $0.25 \times 0.4 \mathrm{~m}$ and $0.25 \times 0.5 \mathrm{~m})$, and both model $26 \mathrm{~B}$ and $26 \mathrm{C}$ $(0.25 \times 0.5 \mathrm{~m})$. The column dimension, moreover, was $0.6 \times 0.6 \mathrm{~m}$, except for model 3 and model 14 (0.6 $\mathrm{m}$ in diameter), model $16(0.65 \mathrm{~m}$ in diameter), and several models; namely 26, 26B, 26C, 27, 27C and 27E; that combined column dimension of $0.6 \times 0.6 \mathrm{~m}$ and diameter of $0.6 \mathrm{~m}$. The thickness of the floor plate for the simulation was $0.12 \mathrm{~m}$ where the concrete quality of the beam/column/floor plate was K-300, the quality of the main reinforcing steel was $\mathrm{Fy}=4000$ $\mathrm{Kg} / \mathrm{cm}^{2}$, and the quality of stirrup steel was Fy = $2400 \mathrm{Kg} / \mathrm{cm}^{2}$. The assumption of the dead load, in addition, was $400 \mathrm{Kg} / \mathrm{m}^{2}$ while the assumption of the live load was $250 \mathrm{Kg} / \mathrm{m}^{2}$ (office buildings function).

The aforementioned data were input to ETABS (in which the modal analysis and eccentricity analysis were conducted) and to Simplified Vulnerability Analysis (SVA) for Architectural Design. The results obtained from the modal analyses were Period (T), Shape Mode Translation (Ux, Uy) and Rotation (Rz), Participating Mass Ratio (Sum Ux, Sum Uy) while outputs from the eccentricity analysis werecenters of mass and rigidity. The results from SVA analyseswere vertical/horizontal irregularities.

By comparing the fundamental period of the building model ( $\mathrm{T}$ ) and the maximum fundamental period (Tmax), the structure's stiffness can be seen (Budiono and Supriatna 2011). If $\mathrm{T}<\mathrm{Tmax}$ then the structure is stiff and if $\mathrm{T}>\mathrm{Tmax}$ then the structure is flexible. The Tmax is based on the earthquake zones in Indonesia which are categorized as "high".

$\mathrm{Ux}, \mathrm{Uy}$, and $\mathrm{Rz}$ are used to assess the level of irregularity. Buildings with dominant translation in mode 1 and mode 2 (Ux and Uy) and rotation in mode3(Rz) can be categorized as regular (Murty et al. 2012).

Sum Ux and Sum Uyare the sums of the contributions each mode towards $-\mathrm{x}$ and $-\mathrm{y}$ axes in the modal analysis. To ensure its accuracy, this method relied on the part participating in the total building mass called Participating Mass Ratio (Hanna et al. 2017). According to the latest earthquake regulations, SNI 1726: 2019, the mass participation ratio must reach $100 \%$ (Badan Standarisasi Nasional 2019). One of the reasons why the mode calculation of one building model cannot reach $100 \%$ is its complexity and/or irregularity. The more complex and/or the more irregular a building is, the more modes needed and the more difficult the calculation mode to reach $100 \%$.

Eccentricity occurs in buildings where the centers of mass and rigidity donot coincide or are eccentric so that it can cause torsion in the building when an earthquake lateral force occurs (Tjokrodimuljo 1997).

Based on FEMA 451B (FEMA 2007) and Simplified Vulnerability Analysis (SVA) for Architectural Design (Teddy et al. 2018), there are two criteria of buildings' geometric configurations, regular and irregular. Irregular configurations, particularly, have two categories namely, horizontal structural irregularities and vertical structural irregularities. Horizontal structural irregularities comprises of Torsional irregularity, Re-entrant Corner (setback) Irregularity, Diaphragm Discontinuity Irregularity, Out of Plane Offsets Irregularity, and Nonparallel Systems Irregularity. Vertical structural irregularities, on the other hand, 
consists of Stiffness (Soft Story) Irregularity, Weight (Mass) Irregularity, Vertical Geometric Irregularity, In-Plane Discontinuity Irregularity, and Strength (Weak Story) Irregularity.

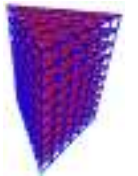

Model-0

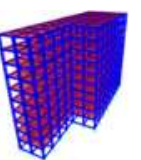

Model-4

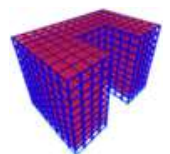

Model-7

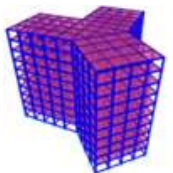

Model-10

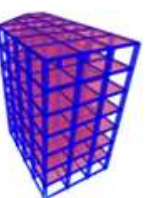

Model-13

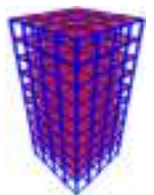

Model-16

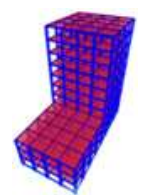

Model-19

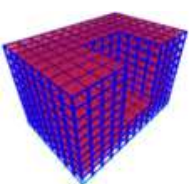

Model-22
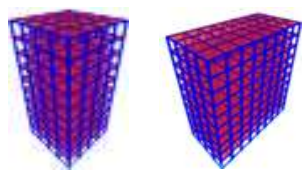

Model-1

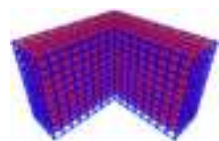

Model-5

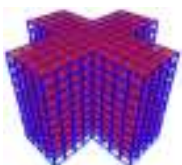

Model-8

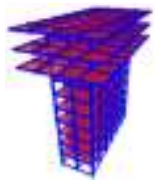

Model-11

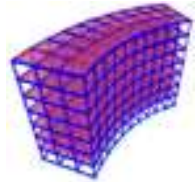

Model-14

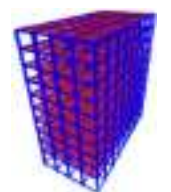

Model-17

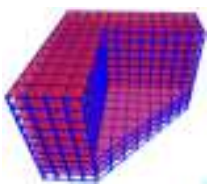

Model-20

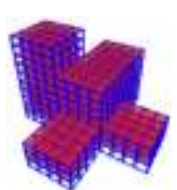

Model-23B

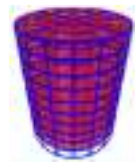

Model-3

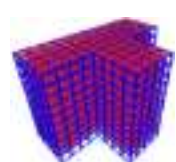

Model-6

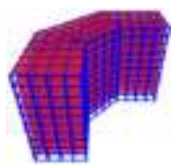

Model-9

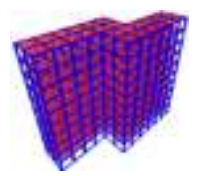

Model-12

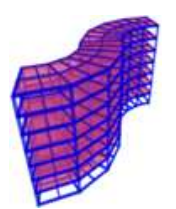

Model-15

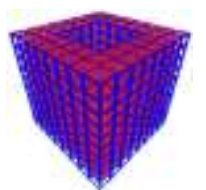

Model-18

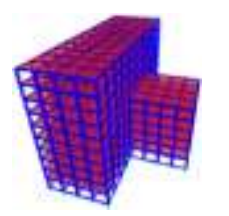

Model-21

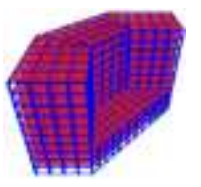

Model-24

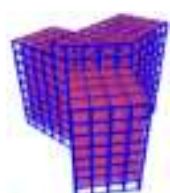

Model-25

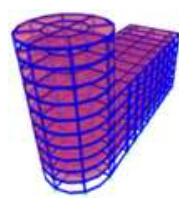

Model-26C

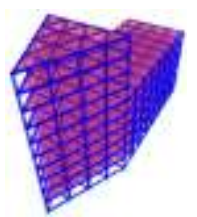

Model-27E

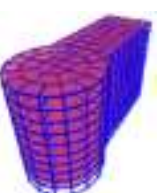

Model-26

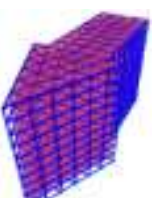

Model-27

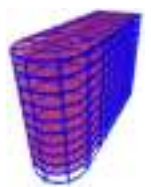

Model-26B

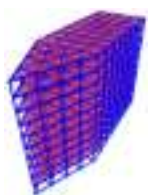

Model-27C
Figure 1. The 32 building models

\section{Result and discussion}

Period $(\mathrm{T})$

From table 1, it can be seen that there are no significant differences between the building's fundamental period $(\mathrm{T})$ and the building's maximum period (Tmax) except for model -11 . This condition means that the other building models are still stiff enough while the model-11 is relatively slender $(\mathrm{H} / \mathrm{D}=4)$ so that it will not be so stiff. Nathan Madutujuh (Madutujuh 2020) proposes the ideal comparison $\mathrm{H} / \mathrm{D} \leqslant 2$ that can reduce over-turning effects, especially in tall buildings.

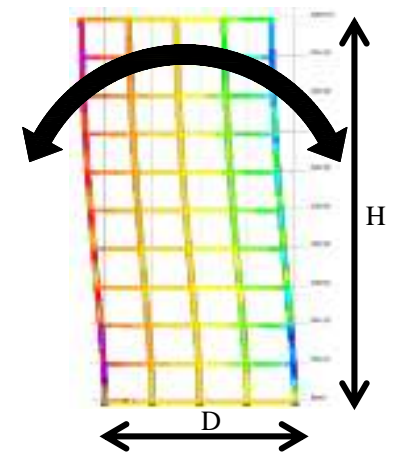

Figure 2. The ideal comparison between height $(\mathrm{H})$ and width (D) of a tall building $\mathrm{H} / \mathrm{D} \leq 2$ to reduce the possibility of over-turning due to an earthquake Source: (Madutujuh 2020) 
Shape mode translation $(\mathrm{Ux}, \mathrm{Uy})$, rotation $(\mathrm{Rz})$ and eccentricity
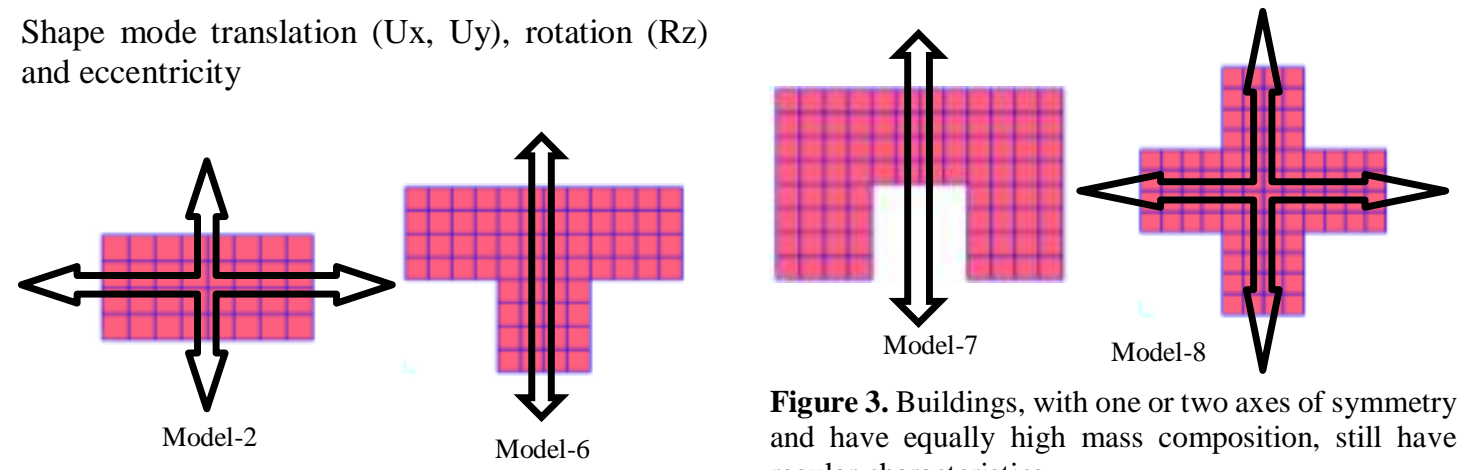

Figure 3. Buildings, with one or two axes of symmetry and have equally high mass composition, still have regular characteristics

Table 1. The results of analysis of modal analysis, eccentricity and SVA of architectural design 32 building models

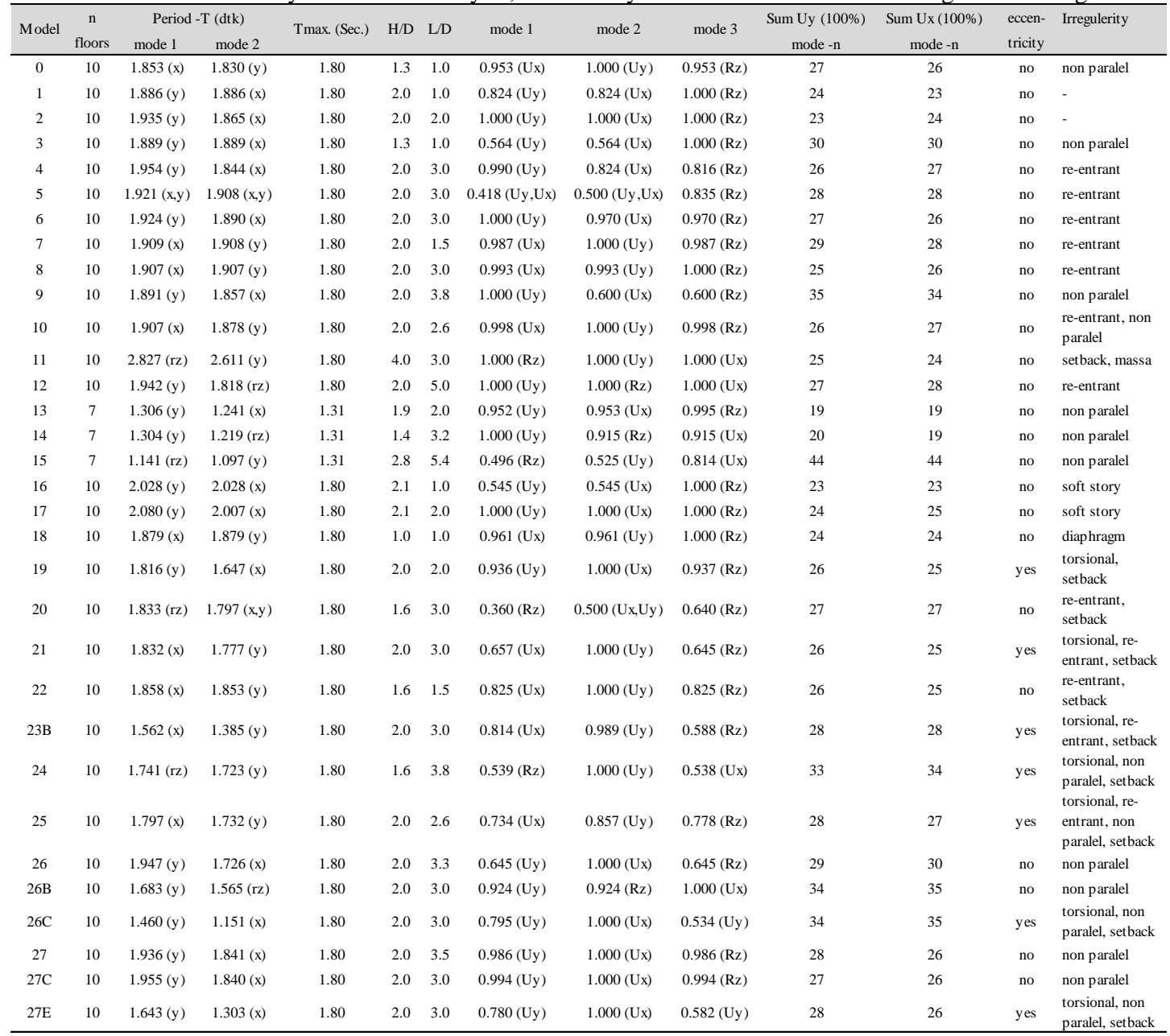

According to FEMA 451B and SVA for Architectural Design, it is only models -1 and -2 that have regular geometric configuration categories. However, from 10 irregular categories based on FEMA 451B, SNI 1726:2019 only disallows buildings with torsional, soft story, and weak storyirregularities. Thus, a building model is categorized as relatively regular if the models 1 and the model -2 are dominant translation (Uxand Uy), the model-3 is dominant rotation (Rz), the eccentricity is not excessive, and there is no soft story/weak story. Of 32 models, only 16 of them that can be included in the category, namely models $-0,1,2,3,4,6,7,8,9,10,13,18$, 
22, 26, 27, and 27C. From these 16 models, furthermore, 14 of them are categorized as symmetrical building models with one or two axes (model -0, 1, 2, 3, 6, 7, 8, 9, 10, 18, 22, 26, 27 and 27C) and have equally high mass composition. In addition, the other two models categorized as relatively regular are models -4 and -13 . These two models are not symmetrically formed by the subtractive transformation, which is not dominant $(\leqslant 15 \%)$. Therefore, their deformation behavior is still dominated by their two-axial symmetrical intact mass.

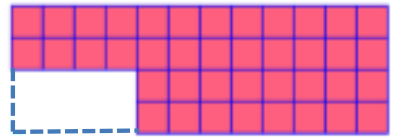

Model-4

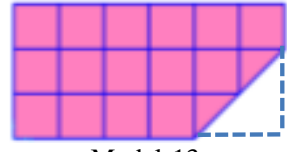

Model-13
Figure 4. Buildings with subtractive results $10 \%-15 \%$ in which their intact mass deformation behavior is symmetrical rectangles with two axes

From all previously mentioned 32 models, most of them still have irregularities (see table 1) like torsional irregularities, re-entrant corner irregularities, diaphragm discontinuity irregularities, non-parallel system irregularities, soft story irregularities, weight (mass) irregularities, and vertical geometricirregularities. Irregularities definitely will cause torsion and concentrations of tension on some parts of buildings (Arnold 2006), but these potential problems can be reduced by using shear walls/core walls and strengthening structures where the concentrations of tension occur.

The mass participation ratio

The number of maximum modes needed to conduct modal analyses of building models is $10 *$ the floor number $(\mathrm{N})$ (Madutujuh 2020). It is after the analyses have been done that the exact number of modes needed to reach $100 \%$ mass participation is known. In addition, the geometric configuration, both vertical and horizontal, can also influence the number of modes. Table 1 and figure 5 shows two 7-floor-building models with relatively simple geometric configurations, model -13 (from the subtractive result) and model -14 (having one-axial symmetrical form), only needs mode 19 and mode 20 to reach $100 \%$ mass participation. Furthermore, to reach a more complex model like model -15 which has nonparallel system irregularities, it needs mode 44 .
For the 10-floor-building model, increasing the number of modes is started by simple models with mode 23 - 25 (models -16, 1, 2, 18, 11, 17). The next levels are firstly dominated by models having two and one axes of symmetry with mode 26 and 27 (models 19, 21, 22, 8, 0, 6, 27C, 10); and then by non-symmetrical models with mode 28 (models 25, 5, 12, 23B). For the last level, models are dominated by non-parallel system irregularities with mode $29-35$ (model -3, 26, 24, $9,26 \mathrm{~B}, 26 \mathrm{C}$ ). The 7-floor-model, model -15, also has non-parallel system irregularities with mode 44. The number of these modes is even beyond the maximum number of modes for the 10-floorbuilding. This condition proves that the more irregular a building is, the more difficult the building reaches $100 \%$ mass participation, hence not recommended structure.

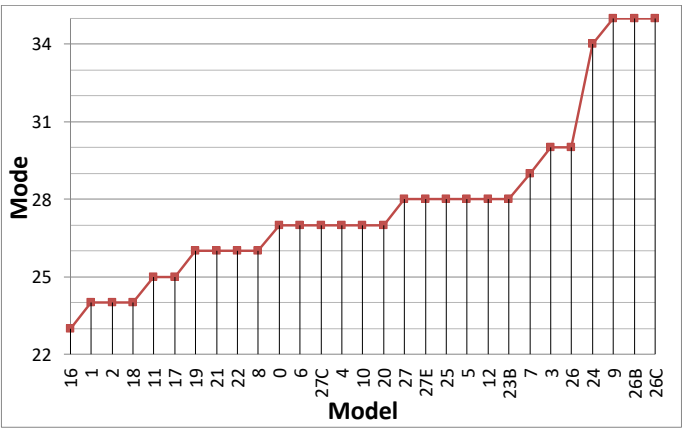

Figure 5. The increasing number of mass participation modes reaching $100 \%$ based on the buildings' irregularity level

\section{Guidance}

From the geometric configuration analyses described above, the guidance in the form-finding process of architectural design is proposed (Goldsmith 2014), and from this guidance, the buildings' geometric configurations relatively resistant to earthquakes are obtained, namely:

1). The comparison between the buildings' height and width.

For the moment resisting frame, limit the buildings' height $(\mathrm{H})$ and width (D) by applying the ratio $\mathrm{H} / \mathrm{D} \leqslant 2$. If $\mathrm{H} / \mathrm{D}>2$, combine it with shear walls and/or core walls.

2). The use of buildings having different heights between floors.

The configuration of stiffness irregularities is sudden diminishing of lateral stiffness in one building/soft story. Such condition usually happens in any building's level if the ratio of the column height of the upper level (h) to the column 
height of the level below (h1) is $\leqslant 0.8$ (FEMA 2007) (figure 6).

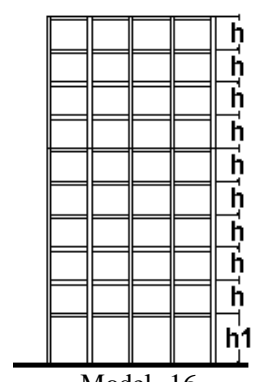

Model -16

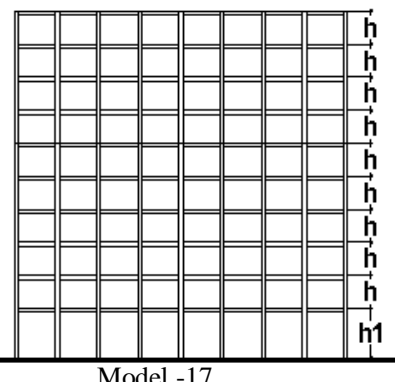

Model -17
Figure 6. Geometric configuration with the ratio of the column height of the upper level (h) to the column height of the level below (h1) is $\leq 0.8$ can cause a soft story

Avoid the geometric configurations that contain soft story especially in strong earthquake zones because soft story is the major cause of the damaged and collapsed buildingsevery time a strong earthquake happens in Indonesia (Boen 2006; 2007a; 2007b).

$3)$. The use geometric configurations of one or two axes of symmetry and the same height.

Though aesthetically monotonous, the basic or primary forms like triangular tubes, square boxes, rectangular boxes, and cylindrical tubes are the regular forms that offer very effective resistance to earthquakes (figure 7).

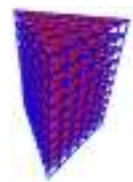

Model-0

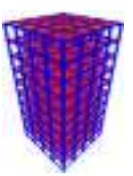

Model-1

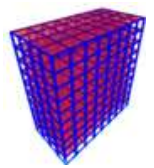

Model-2

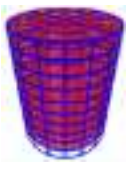

Model-3
Figure 7. Geometric configuration with basic forms liketriangular tube, square box, rectangular box, andcylindrical tube that have good resistance to earthquakes

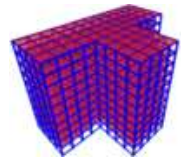

Model-6

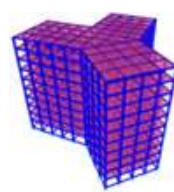

Model - 10

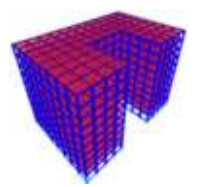

Model - 7

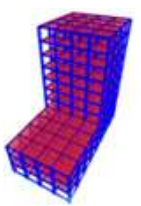

Model - 19

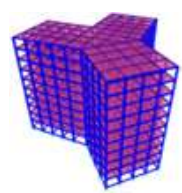

Model - 10
Figure 8. Geometric configurations in one axis of symmetry and in the same height still have relatively regular deformation behavior towards earthquakes

Geometric configurations that have one axis of symmetry and the same heights still have relatively regular deformation behavior towards earthquakes and interesting composition in connection with the aesthetic (figure 8).

4). The use of additive and subtractive transformation mass.

The geometric configuration; created through additive or subtractive processes, $\leqslant 15 \%$ from basic forms; evidently offers relatively effective resistance to earthquakes, and its basic or primary form, as well as its variation, is quite aesthetically interesting (figure 9).

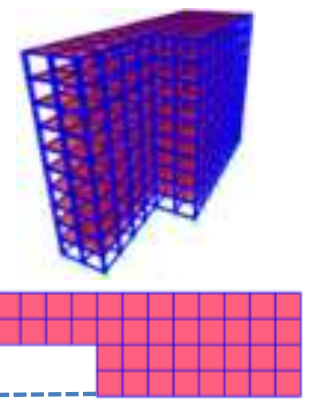

Model-4

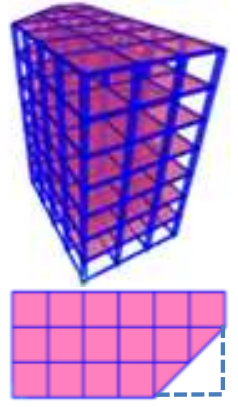

Model-13
Figure 9. Geometric configurations with subtractive mass forms $\leq 15 \%$ are still influenced by the deformation behavior of their intact masses 
5). The use of transformation and compositionforms that have different heights.

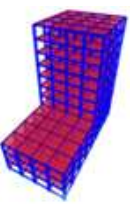

Model-19

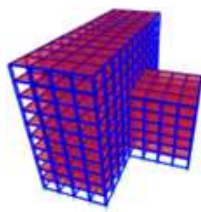

Model-21

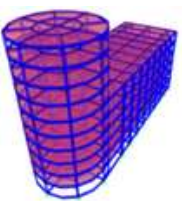

Model-26C
Figure 10. Torsion occurring in geometric configurations with one axis of symmetry mass composition and having different heights can be reduced with shear walls or core walls

Apparently, the occurrence of torsion is more sensitive in the vertical mass composition changes than in the horizontal ones (figure 10). However, if the mass is still symmetrical ( 1 axis minimum), the behavior deformation can still be anticipated in several ways such as using shear walls or core walls for the higher mass to reduce potential torsion.

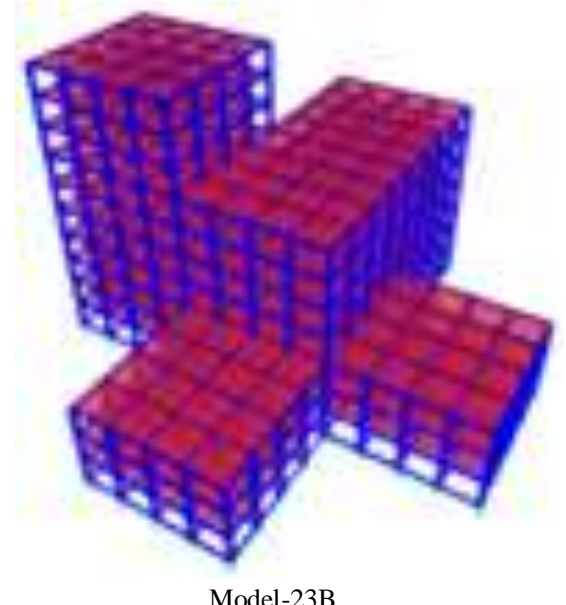

Figure 11. A geometric configuration with random mass composition will also create random deformation behavior

Though it is challenging, building construction having random mass composition or transformation should be avoided since such construction may also cause random deformation behavior which obviously cannot be predicted or anticipated (figure 11).
6). The use of $\mathrm{L}, \mathrm{T}, \mathrm{U},+$, and $\mathrm{Z}$ forms.

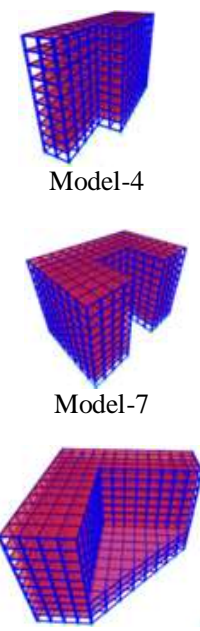

Model-20

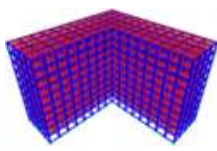

Model-5

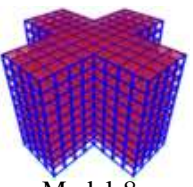

Model-8

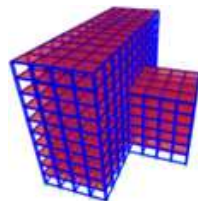

Model-21

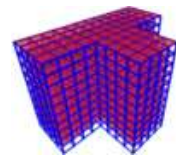

Model-6

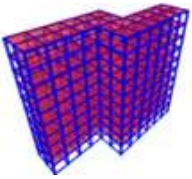

Model-12

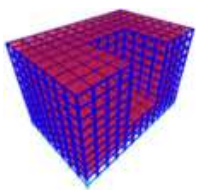

Model-22
Figure 12. Geometric configurations of $\mathrm{L}, \mathrm{T}, \mathrm{U},+, \mathrm{Z}$ have potential torsional and re-entrant corner irregularities

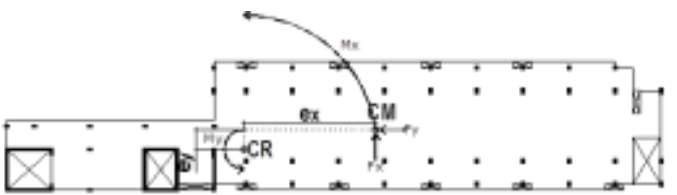

(a)

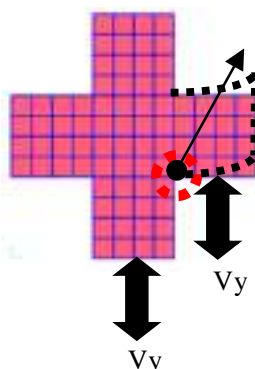

Concentration of tension in structural elements

(b)

Figure 13. (a). Eccentricity (ex, ey) between Center of Mass (CM) and Center of rigidity (CR) that can cause torsion to buildings, (b). The difference between deformation and tension concentration in the + mass form as a result of an earthquake $\left(\mathrm{V}_{\mathrm{y}}\right)$

The $\mathrm{L}, \mathrm{T}, \mathrm{U},+$, and $\mathrm{Z}$ forms (figure 12) have potential torsional irregularities (figure 13a) and re-entrant corner irregularities (figure 13b). To minimize the irregularities, some methods can be applied like strengthening areas where the concentration of tension force as a result of earthquakes is likely to occur (figure 14a), reducing potential torsion by installing shear walls at the tips of the wings (figure 14b), or using 
dilatation to separate the irregular building masses (figure 14c) (adaptation from Duggal (2007)).

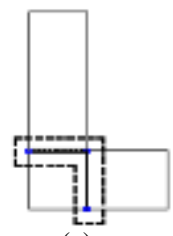

(a)

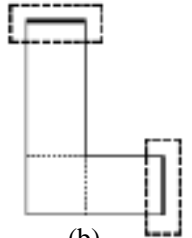

(b)

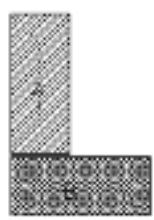

(c)
Figure 14. (a). Strengthen the places where the concentration of tension force potentially occurs, (b). Use shear walls to reduce the potential torsion or, (c). Conduct dilatation to separate the building mass

7). The use of non-axial asymmetrical mass form.

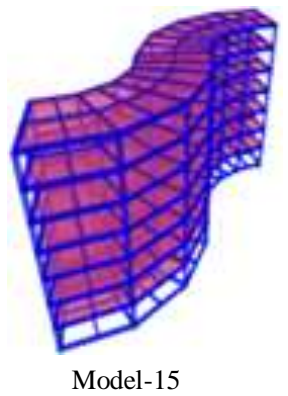

Figure 15. The organic forms that have potential torsional and non-parallel system irregularities tend to have random deformation behavior

The organic geometric configurations are nonaxial asymmetrical forms that potentially have both torsional irregularities and non-parallel system irregularities. If the configurations are complex, it will be difficult to predict buildings' ability to respond to earthquakes. Therefore, although they are architecturally attractive, the organic forms are not recommended formsin strong earthquake zones because they are less resistant to earthquakes (LI 2019).

\section{Conclusion}

Actually, there is no prohibition on designing any kind of building forms in architecture. However, an architect must understand the risks of building damage due to earthquakes and the additional costs for anticipating such disasters. Therefore, "simple is secure" is better than "simple is bore" when it is related to designing buildings in earthquake-prone areas.

\section{Acknowledgment}

This research is fully funded by the PNPB of Engineering Faculty of Universitas Sriwijaya through the SAINSTEK scheme. The authors would like to express their gratitude to Universitas Sriwijaya for the funding program that has made this important research feasible and effective.

\section{References}

Arnold, Christopher. 2006. 'Seismic Issues in Architectural Design'. In Designing For Earthquakes A Manual For Architects FEMA 454. California: Engineering Research Institute (EERI).

Arnold, Christopher, and William W. Stewart. 2000. 'Seismic Analysis and Design'. In The Architects Handbook of Professional Practice, edited by AIA, 13th ed., 1-7. New Jersey: John Wiley \& Sons Inc.

Badan Standarisasi Nasional. 2019. Tata Cara Perencanaan Ketahanan Gempa Untuk Struktur Bangunan Gedung Dan Non Gedung SNI 1726: 2019. Jakarta: Standar Nasional Indonesia.

Boen, Teddy. 2006. 'The Yogya Earthquake 27 May 2006, Structural Damage Report'.

- 2007a. 'Bengkulu \& West Sumatra Earthquakes, September 12, 2007, Structural Damage Report'.

. 2007b. 'West Sumatra Earthquake, 6 March 2007, Structural Damage Report'. In Konstruksi Tahan Gempa Indonesia, edited by HAKI, 1-30. Jakarta: HAKI.

Budiono, Bambang, and Lucky Supriatna. 2011. Studi Komparasi Desain Bangunan Tahan Gempa Dengan Menggunakan SNI 03-17262002 Dan RSNI 03-1726-2012. Bandung: Penerbit ITB.

Duggal, Shashikant K. 2007. Earthquake Resistant Design of Structures. New Delhi: Oxford university press New Delhi.

FEMA. 2007. NEHRP Recommended Provisions for New Buildings and Other Structures: Training and Instructional Materials-FEMA 451B. Washington DC: Federal Emergency Management Agency.

Goldsmith, Nicholas S. 2014. 'Shape Finding or Form Finding?' In Shells, Membranes and Spatial Structures: Footprints, 1-10. Brasil: 
International Association for Shell and Spatial Structures (IASS) with permission. https://ftlstudio.com/wpcontent/uploads/2016/04Form Finding vs Shape Making.pdf.

Hanna, Nagy.F., Ali.M. Elrafei, Magdy.M.M Genidi, and Tamer M. S. Elsaied. 2017. 'Efficient Mass Participation Ratio of Building with Basement'. IOSR Journal of Mechanical and Civil Engineering 14 (01): 59-74. https://doi.org/10.9790/16841401045974.

Hoedajanto, Dradjat, and Muhammad Riyansyah. 2015. 'Bangunan Tahan Gempa Dan Tanggung Jawab Legal Praktisi Konstruksi Indonesia'. In Challenges in the Future, edited by Davy Sukamta, 1-10. Jakarta: HAKI.

Kementerian Pekerjaan Umum dan Perumahan Rakyat. 2010. Peta Hazard Gempa Indonesia 2010 Sebagai Acuan Dasar Perencanaaan Dan Perancangan Infrastruktur Tahan Gempa. Jakarta: Kementerian Pekerjaan Umum dan Perumahan Rakyat. https://pustaka.pu.go.id/biblio/peta-hazardgempa-indonesia-2010-sebagai-acuan-dasarperencanaan-dan-perancangan-infrastrukturtahan-gempa/EB4G9.

LI, Liang. 2019. 'Research on the Function of Architectural Design Based on Seismic Observation Records in Seismic Design of Buildings'. Academic Journal of Environment \& Earth Science 1 (1). https://francispress.com/papers/1013.

Madutujuh, Nathan. 2020. 'Perencanaan Gedung Bertingkat Dengan Program SANSPRO'. In Webinar HAKI. Jakarta: Webinar HAKI.

Murty, C. V. R., Rupen Goswami, A. R. Vijayanarayanan, and Vipul V. Mehta. 2012. Some Concepts in Earthquake Behaviour of Buildings. Gujarat: Gujarat State Disaster
Management Authority Government of Gujarat.

Özmen, Cengiz, and Ali İhsan Ünay. 2007. 'Commonly Encountered Seismic Design Faults Due to the Architectural Design of Residential Buildings in Turkey'. Building and Environment 42 (3): 1406-16. https://doi.org/10.1016/j.buildenv.2005.09.02 9.

Teddy, L., G. Hardiman, Nuroji, and S. Tudjono. 2018. 'Simplified Vulnerabiltiy Analysis (SVA) Preliminary Design of the Frame Structure in the Architectural Design Process'. Indian Journal of Science and Technology 11 (20):

$1-13$. https://doi.org/10.17485/ijst/2018/v11i20/121 768.

Tim Pusat Studi Gempa Nasional. 2017. Peta Sumber Dan Bahaya Gempa Indonesia Tahun 2017. Edited by Masyhur Irsyam, Sri Widiyantoro, Irwan Meilano, Ariska Rudyanto, Sri Hidayati, Wahyu Triyoso, Nuraini Rahma Hanifa, Didiek Djarwadi, and Lutfi Faizal. Kabupaten Bandung: Pusat Penelitian dan Pengembangan Perumahan dan Permukiman Badan Penelitian dan Pengembangan Kementerian Pekerjaan Umum dan Perumahan Rakyat. https://sianipar17.files.wordpress.com/2018/1 2/nsha_2017.pdf.

Tjokrodimuljo, Kardiyono. 1997. Teknik Gempa. Yogyakarta: Nafiri.

\section{Author(s) contribution}

Livian Teddy contributed to the research concepts preparation, methodologies, investigations, data analysis, visualization, articles drafting and revisions.

Johannes Adiyanto contribute to methodology, supervision, and validation.

Husnul Hidayat contribute to methodology, supervision, and validation. 
ARTEKS : Jurnal Teknik Arsitektur, Volume 6 Issue 2, August 2021

pISSN 2541-0598; eISSN 2541-1217 